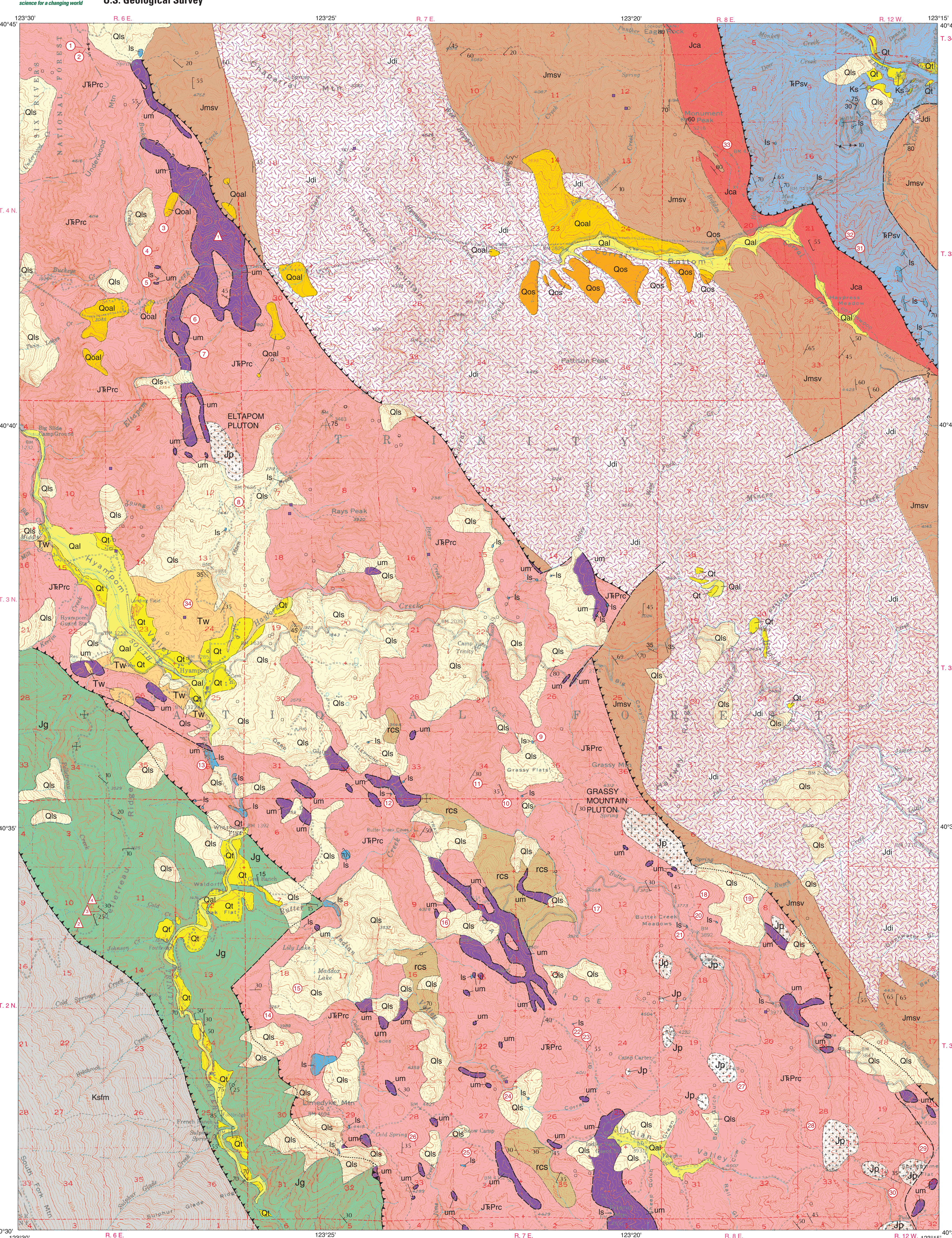

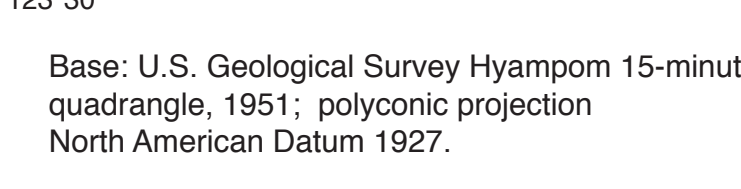

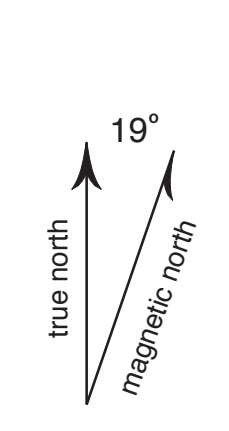

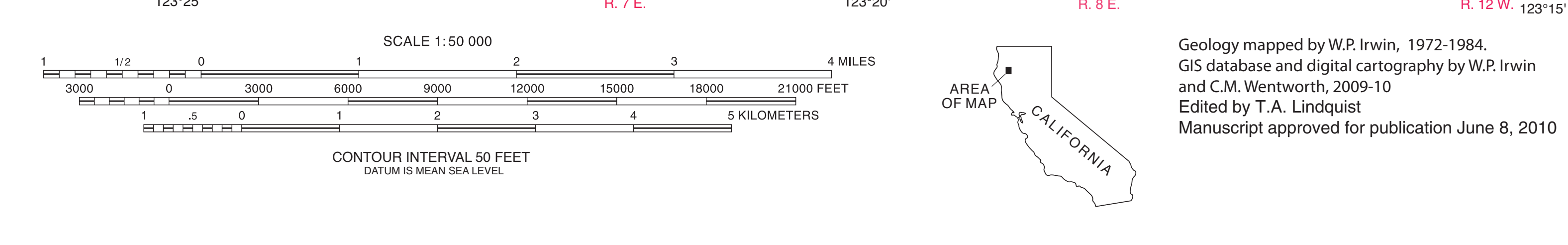

\section{Reconnaissance Geologic Map of the Hyampom 15' Quadrangle, Trinity County, California}

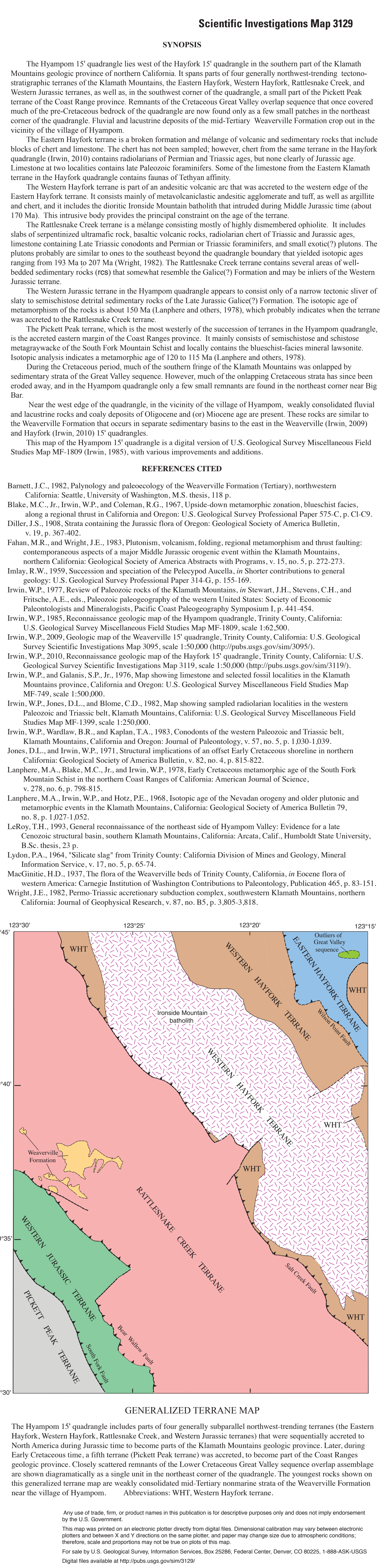

